\title{
The Impact of Music in Increasing Intelligence: A "Gendhing Lancaran" Experiment on Spatial-Temporal Ability
}

\author{
Oriana Tio Parahita Nainggolan \\ Music Department, Institut Seni Indonesia Yogyakarta \\ email: orianatpnainggolan@gmal.com
}

\begin{abstract}
The purpose of this research was to investigate the influence of the Javanese gamelan pieces, namely gendhing lancaran towards the increasing of the spatialtemporal ability. The subjects of this research consist of 60 elementary school students in the fourth grade. By using random methods, those subjects are grouped into two groups those are 30 students on the experiment group and 30 others on the control group. The subjects were assigned to one of two conditions: listening gendhing lancaran (for the experiment group) or no music (for the control group). As a spatial-temporal task, CFIT (culture fair intelligence test) was administered before and after listening gendhing lancaran. The experiment group is scored significantly higher than the non-music group on CFIT. These data support this research as the elements of sounds produced by various music instruments can give stimulus or influence spatial-temporal ability.
\end{abstract}

Keywords: gendhing lancaran, spatial-temporal ability, CFIT.

\section{ABSTRAK}

Tujuan penelitian ini adalah menginvestigasi pengaruh tetembangan gamelan Jawa, yaitu gendhing lancaran terhadap peningkatan kemampuan spasial-temporal. Subjek penelitian ini adalah 60 murid sekolah dasar di kelas empat. Dengan menggunakan metode acak, subjek-subjek tersebut dijadikan ke dalam dua kelompok, yaitu 30 dalam kelompok eksperimen dan 30 lainnya dalam kelompok pengawasan. Mereka dikaitkan dengan salah satu dari dua kondisi: mendengar gendhing lancaran (untuk kelompok eksperimen) atau tidak mendengar musik tersebut (untuk kelompok pengawasan). Sebagai tugas spasial-temporal, CFIT (culture fair intelligence test) dicatat sebelum dan sesudah mendengar gendhing lancaran. Kelompok eksperimen secara signifikan bernilai lebih tinggi dibandingkan kelompok pengawasan melalui CFIT. Data ini mendukung penelitian ini di mana elemen-elemen bunyi yang dihasilkan berbagai alat musik dapat memberikan stimulus atau pengaruh pada kemampuan spasial-temporal.

Kata kunci: gendhing lancaran, kemampuan, spasial-temporal, CFIT. 


\section{INTRODUCTION}

One of the benefits of music is as a medium of education. The use of music in education started since the era of ancient Greece. It is known from the writings of Plato who said that music education has important positions because there is no discipline which can enter the human psyche exceeding the rhythms and harmonies (Black and Moore, 1997: 16).

What is essential from music education, first of all, is not about how to make one becomes an expert in music (music player/musician), but to develop a musical sense in every human being. The ability of the technique in playing an instrument is required when a person has been able to develop a musical sense with the aim to improve the quality of taste he or she wants to be revealed, or when someone decides to become a music player.

Every human being is equipped with the same sense of musical ability (musicality). But the difference is how such a musicality is processed and enhanced. The more often the musicality is being processed, the higher it will be. But again, in this case being the musical does not mean being a musician.

Other benefits of music on the lives of human beings is to improve and encourage the development of the personality and social entity. The development of personality in learning music includes various aspects, namely cognition, reasoning, intelligence, creativity, reading, language, behavioral and social interaction.

The activity of music from an early age gives benefit in all human life. One of the benefits associated with the development of the intelligentsia. The development of the intelligentsia of really needed by human being in everyday life. With a good intelligentsia, someone might be able to resolve a wide range of problems in life.

Improvement of intelligentsia will occur if there is a balance between the two hemispheres of the human brain. The balance between the two hemispheres of the brain can be achieved when one is given a stimulus to stimulate nerve cells of their brains to work actively. With the active nerve cells of the brain process, there was an increase in the intelegensia (Satiadarma and Zahra, 2004: 17-21). 
The music was believed to be an effective stimulus to balance both hemispheres of the human brain. Music -with sound as prime elements- can stimulate the nerve cells of the human brain to be able to work actively. With the active nerve cells in the human brain, there are many skills that can be improved. According to Rauscher and Hinton (2006:234), one of the skills that can be improved through music is the spatial-temporal ability.

Temporal-spatial ability is one of the capabilities seen as a factor that supports the improvement of one's intelligentsia. Temporal-spatial ability is a combination of the two capabilities i.e. the spatial ability and the temporal one. Spatial-temporal ability lies in both hemispheres of the human brain. If the spatial ability is on opposite sides of the right brain, temporal abilities are on opposite sides of the left brain.

Most of the studies that showed a link between spatial-temporal ability and music (Rauscher, et al, 1993; Rauscher and Zupan, 2000; Hetland, 2002), use Western classical music as factors that affect the spatial-temporal ability. Yet not many similar studies which look at the link between spatial-temporal ability and the music outside the Classical West for example such as Javanese gamelan. Therefore, this study looks at the link between the Javanese gamelan (gendhing lancaran) and the spatial-temporal ability.

Gendhing in Javanese gamelan diction has a variety of meanings. Gendhing is meant simply as a musical instrument. Meanwhile, in the context of composition as described by Rahayu Supanggah, it is used to describe a form of gamelan music (musical form) or the song/tetembangan (pieces of song) in Javanese karawitan (2007: 6).

In the quantity, there are hundreds or maybe even thousands gedhing in Javanese karawitan. But that number can be simplified into nine large grouping according to the form, i.e. Lancaran, Srepegan, Sampak, Ayak-ayakan, Kemuda, Ketawang, Ladrang, Merong, and Inggih (Rahayu Supanggah, 2007: 97). 
In its form, gendhing lancaran consists of one gong there with four gatras (counts), kethuk is set in a tone of dhing (on any odd count), kenong is set on each dhong gatra (on each even-numbered count), its tone is always taking a tone of dhong gatra, kempul is housed in a tone of small dhong and one gong blow has three three kempuls, in which the first kempul first emptied.

The term "spatial-temporal ability" is broadly defined as the ability to process specifically mental representations in a space. The activities of the process of mental representations in a space includes: changing mental representations and differentiate in space and time by using the symmetry operation or operation of symmetry (Shawn, 2001:611).

Howard Gardner (1983 and 1993), a psychologist who is famous for its Multiple Intelegence theory said that people who have the spatial-temporal ability is the one who is able to think scientifically and artistically. That is, with a good spatialtemporal ability, one can not only count the mental image properly (scientifically), but can also draw up the mental images taking into account a proportionate place (artistically).

The importance of the spatial-temporal ability can be seen through the explanation of Arnheim (1969:1) who said that, our perception of the world around us is based on cognitive processes. Arnheim explained that a very good mechanism obtained is based on our understanding of the environment around us, all of which can be identified and described by using the psychology, that cognitive processes are part of the area of the world of imagination. Further Arnheim said that someone cannot think of something clearly, if he or she doesn't have a mental picture of what he or she thought. Mental picture can be obtained by using spatial-temporal ability.

Spatial-temporal reasoning needs to be distinguished from the operation of symmetry (symmetry operations). There is a symmetry operation in a process called synchronization. The synchronization process with regard to the activity of the frontal cortex and the right hemisphere pariental cortex of the human brain at the time of the mental rotation when composing separate mental images (Bhattacharya, et al, 
2001). Meanwhile, according to Leng and Shaw (1991), operation of symmetry in the human brain cell network appears when one got the extrinsic stimulus on long-term memory. But this symmetry operation is also found in short-term memory when the mental images of being processed (on process of thinking). The order in the process of merging the mental images in parts of the brain is called the temporal repetition of a stimulus. In other words, the brain automatically detects the change in sound (Rauscher et al, 2001:33).

Trion model theory, developed by Leng and Shaw, is a neuroscientific framework to look at the link between music and spatial-temporal ability. Due to the structure model of trion, some ring patterns of neural arranged in a spatial-temporal code is very complicated in a part of the cortex. Referring to this model, early childhood sensitivity towards music and early childhood brain tissue that is still overwhelmingly plastis; listening to music can affect neural development-the same neural capabilities that are affected by environmental stimulation (Friedman,et.al. 1997:3870). In particular, Leng and Shaw (1991) state that musical activity provides an opportunity to develop the spatial-temporal ability.

Trion model theory is also supported by the revelation that says music is a means to integrate the two parts of the brain (Jensen, 2000 in Bennett and Bennett, 2008:84). That is, if a synchronization occurs between the two cerebral hemispheres (cerebral hemisphere synchronization), the human learning process will be optimal. This optimization of the process of learning occurs because of the active neurons of the human brain that got stimulus of the music.

\section{METHODOLOGY}

The subjects of this research comprise 60 students and students of class IV in Elementary School of Suryodiningratan III Yogyakarta, Indonesia, which was grouped into two, namely the experiment group (30 students) and the control group (30 students). Grouping the subjects is done through a random method. 
The procedure of research conducted in this study is testing the normality of the data from the subjects by using tests of CPM (coloured progressive matrices). The next procedure is testing the ability of spatial-temporal subjects of research (pretest) by using the CFIT (culture fair intelligence test). The next step is giving preferential treatment to the subjects of research (the experiment group) that listen to gendhing lancaran. After providing treatment to the experiment group, spatialtemporal abilities of the two groups of the research subjects was tested again using the CFIT.

\section{RESULTS AND DISCUSSION}

Normality test is performed using the Kolmogorov-Smirnov with the highest level of significance (a) 0.05 (5\%). The test is done with SPSS 17 for Windows. Data can be said to be normally distributed if the $p$-value is the value in the asimp column. SIG (2-tailed) < level of significance ( $\alpha$ ). The SPSS output shows a group of experiments has $p$-value in a column asimp. Sig (2-tailed) of $0.627>$ level of significance, amounting to 0.05 . While the control group has the $p$-value is the value in the asimp column. SIG (2-tailed) for 0.429 > level of significance, amounting to 0.05 . It can be said that the data on these two groups have distributed normally. 
Table 1.

SPSS output through Kolmogorov-Smirnov.

One-Sample Kolmogorov-Smirnov Test

\begin{tabular}{|ll|r|r|}
\hline & $\begin{array}{c}\text { Skor CPM } \\
\text { Kelompok } \\
\text { Eksperiment }\end{array}$ & $\begin{array}{c}\text { Skor CPM } \\
\text { Kelompok } \\
\text { Kontrol }\end{array}$ \\
\hline N & 30 & 30 \\
Normal Parameters a,b & Mean & 32.1333 & 31.8667 \\
Most Extreme & Std. Deviation & 2.54251 & 2.27025 \\
Differences & Absolute & .137 & .160 \\
Kolmogorov-Smirnov Z & Positive & .130 & .128 \\
Asymp. Sig. (2-tailed) & Negative & -.137 & -.160 \\
\hline
\end{tabular}

a. Test distribution is Normal.

b. Calculated from data.

After the data has been known to be distributed normally, the next thing is to test the spatial-temporal ability of the experiment group and the control group on pretest and posttest stage. This testing is done using the t-test analysis techniques (difference test). This difference test will see if there is a difference of the results at the stage of pretest and posttest on the group who listen gendhing lancaran. It also uses a difference test of the value of the level of significance ( $\alpha) 0.05(5 \%)$. The guidelines are used to see if there is a difference after listening gending lancaran is if the the p-value in column sig $(2$-tailed) $<$ level of significance $(\alpha)$. Based on the SPSS output on the stage of the pretest and posttest, the experiment group has $p$ value of $0.000<0.05$ level of significance. While the control group has the $p$-value of $0.000<0.05$ level of significance. 
Table 2.

The SPSS output from the t-test in the experiment group.

Paired Samples Test

\begin{tabular}{|c|c|c|c|c|c|c|c|c|c|}
\hline & \multicolumn{5}{|c|}{ Paired Differences } & \multirow[b]{3}{*}{$\mathrm{t}$} & \multirow[b]{3}{*}{$\mathrm{df}$} & \multirow[b]{3}{*}{ big. (2-tailed } \\
\hline & & \multirow[b]{2}{*}{ Mean } & \multirow{2}{*}{ std. Deviation } & \multirow{2}{*}{$\begin{array}{l}\text { Std. Error } \\
\text { Mean }\end{array}$} & \multicolumn{2}{|c|}{$\begin{array}{l}95 \% \text { Confidence } \\
\text { Interval of the } \\
\text { Difference }\end{array}$} & & & \\
\hline & & & & & Lower & Upper & & & \\
\hline $\begin{array}{l}\text { Pair } \\
1\end{array}$ & $\begin{array}{l}\text { Skor CFIT Pretest } \\
\text { Eksperiment - Skor C } \\
\text { Postes Eksperiment }\end{array}$ & 5.70000 & 1.68462 & .30757 & 6.32905 & 5.07095 & -18.533 & 29 & .000 \\
\hline
\end{tabular}

\section{DISCUSSION}

From the results of the analysis of the t-test data that has been implemented, it is found differences of spatial-temporal ability at the time of before and after listening gending lancaran in the experiment group. The differences in the spatialtemporal ability also occurred in the control group. From the two groups of the subjects, it is known that in the experiment group there was a significant improvement against the spatial-temporal ability, whereas in the control group it also occurred differences in the spatial- the temporal ability, but the differences in the control group are a decrease in the spatial-temporal the ability. 


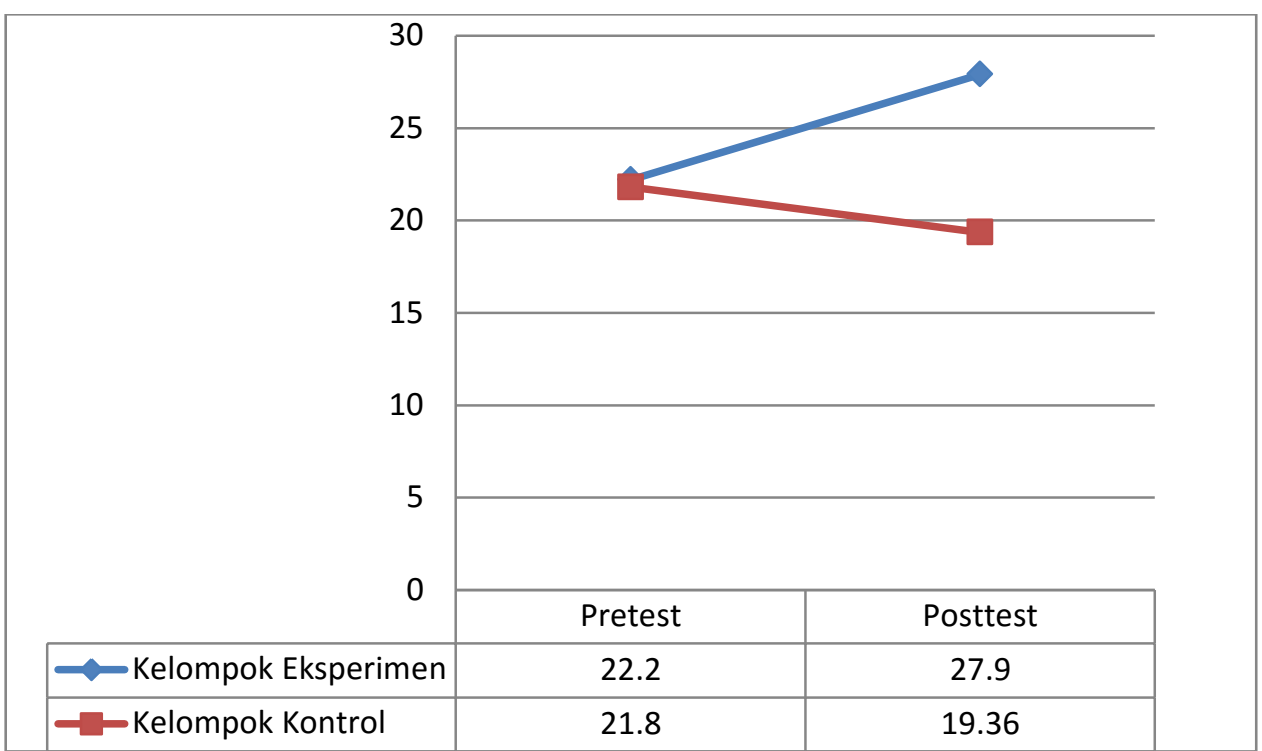

Figure 1.

The mean of pretest and posttest spatial-temporal abilities.

The findings of this research supports the theory advanced by Leng and Shaw (1991) about the trion model. Based on the trion model, music had an influence on brain performance. The relationship between music and the work function of the brain is located on the concept that music helps to improve the performance of the brain through the relationship between the spatial-temporal pattern and the two hemispheres of the brain. Music through sound elements worked to turn both the two brain hemispheres. It can be said that music trains and improves one's brain function.

The performance activity of the two brain hemispheres is assisted with the operation of symmetry (symmetry operations). According to Leng and Shaw (1991), the symmetry operation is already embedded in human brain cells. This symmetry operations will be active if there is a stimulus that comes from human sensing. The active symmetry operations will also enable human long term memory. Not only improves long term memory, the symmetry operations also help to improve short term memory at the time of processing the mental images that are the actual process of thinking. Analogous with this research, when the subjects listen gendhing 
lancaran, at the same time, there was a working process of symmetry operations. The working process of symmetry operations occur through sensing (auditory senses) of the subjects when listening gending lancaran. After listening gending lancaran, the research subjects are tested with CFIT to test the spatial-temporal ability of the subjects of research. From the results of CFIT after listening gendhing lancaran, it is known there is an increase in CFIT score compared to the score before the subjects listen to gendhing lancaran.

The results of this research prove that the human brain can automatically detect sound and enable the performance of brain cells. The activity of the human brain cells provides a chance at improving a person's intelligence. The common sense which said that the stimulation of music (mainly Western music arts) could increase the intelligence is often misinterpreted. Many people say that the stimulation of music can increase the size of the brain. When his or her size of the brain is bigger, someone is considered more intelligent than children who have "normal" brains.

The right thing is that music can't increase the size of the human brain, since theoretically, the brain size is not directly proportional to the level of intellectual intelligence. The real role of music is stimulating the growth of brain cells mainly dendrite cells (part of the neuron that receives neural impulses from other neurons) and axons (part of the neuron that connects the body cells with other cells through a kind of intersection called synapses) that acts as a liaison intercells in the brain. With the greater number of dendrite and axon are owned by a person, the person's ability to catch the message, understand the meaning, and make decisions will be faster. People who are able to take decisions quickly and precisely would normally be described as someone who has a high level of intelligence.

The results of this research also proves that all musical activity, through music training or listening music, has potentially influential to strengthen and improve the relationship between brain hemispheres. With the rise and rise of the relationship 
of the two hemispheres in the brain, as well as potentially increasing the spatialtemporal ability in both the brain hemispheres.

Intelligence obtained through musical activity is highly relevant to the spatialtemporal ability (Gromko and Poorman, 1998; Mallory and Philbrick, 1995; Rauscher, et al, 1997). This is because the musical elements of a piece of music composed in a spatial and temporal manner. For example, when playing or listen to a melody, there is a pattern in it that the construction activities in these patterns contain elements of note, which is compiled by using spatial-temporal code. Music and spatial-temporal ability are two things that complement each other and forming cross-sensory perception. According to Tunks (1992), cross-sensory-related information through the inclusion of one hemisphere and from this hemisphere, the information is forwarded to the other hemisphere.

\section{CLOSING}

Spatial-temporal improvement can potentially increase a person's intelligence. However, this does not mean that to get good intelligence is without going through the stages of learning. The learning process will still take place in the human brain during the human life. But how many the abundance of the learning process, how the quality of learning, and what the learning guidance, and how far the environmental influence will be at which the human lives is a choice. The option to participate in musical activities such as listening to music or even playing music, will still help and keep the brain cells constantly working and enable both the hemispheres of the human brain.

\section{REFERENCES}

Arnheim, R. 1969, Visual Thinking, University of California Press, Berkeley.

Bennet, D., and A. Bennet. 2008. "Engaging Tacit Knowledge in Support of Organizational Learning". VINE 38 (1): 72-94.

Bhattacharya, J; Petsche, H; Feldmann, U; Rescher, B. 2001. "EEG Gamma Band Phase Synchronization between Posterior and Frontal Cortex during Mental Rotation in Humans", Neuroscience Letters, 311, 29-32. 
Black, Julia Schnebly; Moore, Stephen F. 1997. The Rhythm Inside, Rudra Press, Portland, Pregon.

Friedman, H. R; Davachi, L; Rakic P. S. G. 1997. "Differential Activation of the Caudate Nucleus in Primates Performing Spatial and Nonspatial Working Memory Tasks". The Journal of Neuroscience, 17 (10), 3870-3882.

Gromko, J; Poorman A. 1998. The effect of music training on preschoolers' spatialtemporal task performance, Journal of Research on Music Education, 46(2), $173-181$.

Hetland, L. 2000, "Listening to Music Enhances Spatial-Temporal Reasoning: Evidence for The "Mozart Effect", Journal of Aesthetic Education 34, 105-48.

Jensen. 2000. Brain-Based Learning, Corwin Press, Thousand Oaks, CA.

Leng, X; Shaw, G. L. 1991. "Towards A Neural Theory of Higher Brain Function Using Music As A Window". Concepts in Neuroscience, 2, 229-258.

Mallory, M. E; Philbrick, K. E. 1995. "Music Training and Spatial Skills in Preschool Children". Paper presented at the America Psychological Association of Music, New York.

Rauscher, F. H; Shaw, G. L; Levine, L. J; Wright, E. L; Dennis, W. R; Newcomb, R. L. 1997. "Music Training Causes Long-Term Enhancement of Preschool Children's Spatial-Temporal Reasoning". Neurological Research, 19(1), 1-8.

Rauscher, F.H; Shaw, G.L; Ky, K.N. 1993. "Music and Spatial Task Performance". Nature, 365, 611.

Rauscher; Hinton. 2006. "The Mozart Effect: Music Listening is not Music Instruction”, Educational Psychologist, 41, 233-238.

Rauscher, F. H; Zupan, Mary Anne. 2000. "Classroom Keyboard Instruction Improves Kindergarten Children's Spatial-Temporal Performance: A Field Experiment", Early Childhood Research Quarterly, 15 (2), 215-228.

Russeler, J; Alten Muller, E; Nager, W; Kohlmetz, C; Munte, T. 2001. "Event Related Brain Potentials to Sound Omissions Differ in Musicians and Non-Musicians", Neuroscience Letters, 308, 33-36.

Satiadarma, M; Zahra, R. 2004. Cerdas Dengan Musik. Puspa Swara, Jakarta.

Shawn G. L. 2001, "The Mozart Effect”, Epilepsy \& Behavior, 2, 611-613.

Supanggah, Rahayu. 2003. Bothekan I. ISI Surakarta Press.

Supanggah, Rahayu. 2007. Bothekan II. ISI Surakarta Press.

Tunks, T. W. 1992, Handbook of Research on Music Education Teaching and Learning, Schirmer Books, New York. 